\title{
A tortura representada no conto o fato completo de Lucas Matesso
}

\author{
Maria Genailze Chaves \\ Universidade Federal do Pará, Brasil \\ (iD) https://orcid.org/0000-0003-3088-9309 \\ maria.genailze@gmail.com \\ Francisco Pereira Smith Júnior \\ Universidade Federal do Pará, Brasil \\ (D) https://orcid.org/0000-0002-6336-9249 \\ fsmith@ufpa.br \\ Ana Lilia Carvalho Rocha \\ Universidade Federal do Pará, Brasil \\ (i) https://orcid.org/0000-0001-8739-5786 \\ liliarocha@ufpa.br
}

\section{Introdução}

A literatura desde seus primeiros escritos sempre trouxe marcas históricas e socias dentro do seu processo de reflexão e interpretação. Através da mimese buscou imitar o mais verossímil quanto a realidade 
vivenciada pelo corpus social. Até os dias atuais esse processo narrativo se firma e traz à tona uma variedade de cânones que evidenciam a riqueza fictícia a partir do real nos escritos. Por esse viés, e com um objetivo ainda mais aguçado, além de narrar e descrever o real, a partir do século $\mathrm{XX}$, diante das muitas atrocidades que se seguiram, surge na literatura uma nova representação da realidade, então, pautada no testemunho, a literatura se molda como narrativa de juízo, dando voz e fazendo justiça aos marginalizados e injustiçados naquele período.

Diante disso, experiências traumáticas, acontecimentos catastróficos e processos memorialistas tornaram-se marcas registradas nos estudos literários em âmbito mundial, já que essa época foi marcada por uma hierarquia de barbaridades como: genocídios em massa, duas guerras mundiais, várias guerras civis, ditaduras militares, entre outros conflitos que resultaram em milhares de pessoas torturadas e mortas em todo o planeta.

Posto isso, com base no conto $O$ fato completo de Lucas Matesso (1997) de Luandino Vieira, texto ficcional que representa o ditatorialismo na Angola, a presente pesquisa, a partir do comparativismo, consiste numa análise interdisciplinar da tortura representada no texto, percebendo como se deu sua atuação através das atrocidades sofridas pelo personagem principal Lucas Matesso. Nesse viés, como se estabelece as experiências traumáticas nessa narrativa? Essa é uma questão base a ser refletida nesse trabalho, em que:

[...] Não é preciso passar por uma catástrofe, no sentido geológico, biológico, ou histórico, para reconhecer as contingências traumáticas da experiência, como se representa em obras e textos fundamentais do presente. O que aconteceu deixou marcas. As marcas deixam que o acontecido retorne. (NESTROVSKI; SELIGMANN-SILVA, 2000, p. 7-8) 
Em concomitância com essas violências que fazem parte da história, a tortura, em seus vastos meios de representação, é um tema na literatura desde os primeiros escritos. Contudo, desde o século XX essa temática tornou-se marca registrada dentro dos estudos de resistência, sejam eles nos estudos literários brasileiros como em âmbito mundial. Sendo assim, este trabalho tem por objetivo refletir a temática da tortura demarcada no conto através de experiências traumáticas, observando sua representação a partir do corpo torturado presente no texto literário. Diante disso, especificamente, objetiva-se, também, compreender como se deu o salazarismo na Angola, explorando a relação entre o texto, o período histórico e a vida do autor.

A pesquisa de caráter qualitativo desenvolveu-se a partir do método comparatista, uma vez que se mostrou o mais plausível para um melhor aprofundamento da mesma. Machado e Paugeaux (2011) relata que é necessário compreender que este método baseia-se em função da capacidade crítica que o pesquisador tem em relação ao objeto estudado, que em hipótese alguma deve deixar de considerar a relação entre o real vivido e o que há nos textos, além de considerar a realidade historicamente determinada, em que utiliza a integração de estudos diferentes (interdisciplinaridade) e a integração entre os textos (intertextualidade), para repensar a sua maneira e idealizar a literatura, e como se escreve a história literária.

Considerando que a tortura é um desrespeito a dignidade humana, o qual é parte oculta da história mundial, o presente artigo tem como hipótese que a narrativa estudada, através da temática da tortura, reflete questões sociopolíticas veladas pelas ideologias dominantes, e concomitante a isso, por meio do seu teor testemunhal, as descrições nelas exploradas, vêm tornar público e fazer justiça a essas milhares de vozes que foram e ainda são silenciadas não somente na África, 
mas em todos os continentes que de alguma forma são vítimas de sistemas opressores colonialistas e racistas.

\section{A relação entre a ditadura na Angola e a vida de Luandino Vieira}

Muito já se é comentado sobre a situação do colonialismo em que a África até poucos anos se encontrava, vítima de uma multiplicidade de atos violentos e opressores, durante séculos viu-se presa a um processo de exploração e escravismo, que vitimava e violentava os seus nativos. Até os dias atuais encontram-se inseridos em um meio de preconceitos racistas e xenofóbicos.

Diante disso, de mil quatrocentos e oitenta e dois até mil novecentos e sessenta e um a Angola, um país localizado na costa ocidental da África, via-se inserida em vários episódios de violência. Seu período de colonialismo durou quase 5 séculos, até a chegada dos grupos e movimentos de libertação, que lutaram para dar a liberdade e independência a esse país que por 479 anos estava preso a um processo injusto e bárbaro de exploração. O início desse processo de colonização se deu quando no ano de 1482 os portugueses em seus trajetos marítimos partiram para a Índia em busca das suas especiarias, o qual atracaram na Foz do rio Zaire, mantendo a partir daí contato com os africanos (HISTÓRIA DE ANGOLA, 1965).

Outro ponto que marca a colonização do povo angolano diz respeito a uma nova fase de violência que se viram inseridos após o fim da escravatura, em que, segundo Martins (1920), os escravizadores buscavam outros meios de forçar e obrigar o trabalho negro, velando os velhos tipos de escravidão. No ano de 1928, a pasta de finanças de Portugal passa a ser assumida por Antonio Oliveira Salazar, político 
português associado ao regime autoritário do Estado Novo, ${ }^{1}$ permanecendo no poder até setembro de 1968. Durante quarenta anos ele ficou no poder e "começou a formular sua visão para o futuro de Portugal; por outro, Salazar provocou confronto atrás de confronto entre as facções militares até só ele ficar de pé” (MENESES, 2011, p. 99). A partir desse período ele tomou o poder e se tornou ditador. ${ }^{2}$

Segundo Rosas (1989), a longa duração do governo de Salazar é resultado de ordens externas e internas que, através de acordos, estabilizaram o seu Estado Novo. Essas razões externas e o fato de Lisboa colonizar, levaram Salazar a adotar uma política que se caracterizava pelo nacionalismo extremado.

No fundo, a história do salazarismo e da vida política do seu chefe vai ser a da capacidade e possibilidade de defender, adaptar, reformular este sistema de equilíbrios às diversas conjunturas e acidentes de percurso. Esta essência equilibrante do regime decorrente das debilidades estruturais da burguesia portuguesa, esta sua preocupação constantemente ensaiada de não romper a frente de todos os setores sociais dominantes entre si e destes com as classes intermédias, tendo um preço real em termos de desenvolvimento econômico do país, parece dever considerar-se como um elemento central na capacidade de durar demonstrada pelo Estado Novo. (ROSAS, 1989, p. 22)

Diante disso, segundo Wheeler e Pélissier (2009), Salazar instaurou na Angola um processo de colonização que desumanizava os nativos, o qual a partir de 1930 estabeleceu regras para controlar as colônias. Baseava-se nas explorações do trabalho nativo, firmando os portugueses em áreas de além-mar. A partir de contratos, Salazar velava o trabalho forçado, além de uma grande discriminação econômica e

\footnotetext{
${ }^{1} \mathrm{O}$ Estado Novo ou Salazarismo fora o período governado por Salazar fruto do golpe militar que extinguiu a República em 1926.

${ }^{2}$ Ditador é aquele que, investido no governo, concentra em suas mãos todos os poderes do Estado, usando em alguns casos da prepotência.
} 
social, mesmo tentando demonstrar princípios de sociedades multirracial. Assim, criou-se uma sociedade colonial extremamente dividida entre brancos, negros e indígenas.

Sendo assim, no governo militar de Salazar ainda se encontrava na Angola uma grande exploração de mão de obra dos angolanos, com uma precária situação de subsistência, com baixos salários, repressão e discriminação, gerando muitas rebeliões e concomitante a isso, propiciou o início da guerra na Angola $^{3}$ (WHEELER; PÉLISSIER, 2009).

Segundo Costa Pinto (1989), o salazarismo é identificado como um regime político, econômico e social autoritário, sem uma liderança carismática e, com um único partido, atribui ideologias de expansão que apresentava tendências opressivas. Mazula (1995) evidência que, em 1954, o continente africano era considerado como "complemento cultural da Europa, necessário à sua vida, à sua defesa, à sua subsistência. [...] uma reafirmação do princípio atual da exploração colonialista do trabalho obrigatório que sucedeu à escravatura” (MAZULA, 1995, p. 254-323).

Um fator importante para a independência angolana fora o V Congresso Pan-Africano, que ocorrera em Manchester no ano de 1946, sendo escrita a “Declaração aos Povos Colonizados”, pelo Dr. Kwame Nkrumah. Criou-se também, nesse período, um Comitê Regional de Delegados, considerada a primeira formação política organizada. Outro fator marcante para esse processo de descolonização fora a criação da Organização das Nações Unidas (ONU) e Organização da Unidade Africana (OUA), que se transformaram em palanque do anticolonia-

\footnotetext{
${ }^{3}$ A guerra na Angola iniciou no dia 04 de fevereiro de 1961, quando angolanos ligados a grupos de libertação reuniram-se contra o governo Salazar, atacando a casa de reclusão militar em Luanda. Seu fim fora no dia 11 de novembro de 1975 com a independência da Angola. (VISENTINI, 2012).
} 
lismo militante.

Ao final da Segunda Guerra Mundial, e com Salazar ainda no poder, surgiam na África grupos contra a ditadura, gerando, assim, uma nova etapa na história nacionalista africana, o qual usando-se da crise colonialista europeia difundiam-se no pós-guerra, mostrando que “os brancos e seus Estados podiam ser derrotados, total e vergonhosamente” (HOBSBAWM, 1995, p. 212).

Diante desses grupos que surgiam, dois foram de grande importância para o processo de independência da Angola, o Movimento Popular de Libertação Angolana (MPLA) e o União das Populações do Norte da Angola (UPNA), posteriormente conhecida como União das Populações da Angola (UPA); cada um com suas pautas políticas e seus apoios sobreviveram a (Polícia Internacional e de Defesa do Estado) PIDE, governada tanto na Europa quanto na Angola por Salazar. Desse modo,

O branco angolano, de nascimento ou de coração, sentia-se diante do seguinte dilema: de um lado, o MPLA, marxista, comunista, mas com o apoio da Metrópole. Do outro, a FNLA, anticomunista, próOcidente, nacionalista, mas... Formada pela antiga UPA, que "massacrara os brancos de 1961", os "sanguinários tribalistas do Norte”. Portanto, os brancos preferiam o meio termo, nem o marxismo de Agostinho Neto, nem o poder da força do Holden Roberto, o tribalismo negro. Surgia, assim, a UNITA. (CASCUDO, 1979, p. 2).

O historiador Wheeler (2009) expõe que a revolta teve início no norte da Angola em 15 de março de 1961, em que atacaram fazendas e postos administrativos dos portugueses. Em 1974 a revolução dos cravos liderada pelo Movimento das Forças Armadas (MFA) derrubou o regime ditatorial salazarista do Estado Novo. Esse movimento buscava estabelecer liberdades democráticas que buscavam promover mudanças sociais no país. Houve uma aceitação em massa desse mo- 
vimento de resistência, o que gerou um enfraquecimento militar por parte dos europeus.

Segundo Visentini (2012), devida à revolução de cravos foi reconhecida a independência angolana, sendo convidados para formar um governo de transição os três principais movimentos de libertação angolana (MPLA, UNITA e FNLA). Diante disso, em 15 de janeiro de 1975 foi assinado o acordo de Alvor entre o governo português e os três principais movimentos de libertação angolano, estabelecendo a partir desse acordo parâmetros de partilha de poder sob a Angola. ${ }^{4}$ Em 1975, estabeleceu-se uma nova administração formada por representantes dos três movimentos, os quais ficariam no governo até a proclamação oficial da independência da Angola, que ocorrera em 11 de novembro de 1975. Mesmo com sua independência, os conflitos não tiveram fim, houve dois governos paralelos, já que o MPLA declarou, em Luanda, após a saída das autoridades e das últimas tropas portuguesas, a República Popular de Angola, enquanto isso a FNLA e a UNITA proclamavam, em Huambo, a República Democrática de Angola.

Adentrando a vida do autor, José Vieira Mateus da Graça, ${ }^{5}$ cujo pseudônimo é José Luandino Vieira, fora um escritor luso-angolano

\footnotetext{
${ }^{4} \mathrm{~A}$ recusa em conceder independência às colônias africanas estimulou movimentos guerrilheiros de libertação em Moçambique, Guiné-Bissau e Angola. Em 1968 Salazar sofreu um derrame cerebral e foi substituído por seu ex-ministro Marcelo Caetano, que prosseguiu com sua política. A decadência econômica e o desgaste com a guerra colonial provocaram descontentamento na população e nas forças armadas. Isso favoreceu a aparição de um movimento contra a ditadura. (In: historiadomundo.uol.com.br. Acessado em 17 de junho de 2020).

${ }^{5}$ Suas principais obras foram: A cidade e a infância, publicada em 1960; A vida verdadeira de Domingos Xavier, escrito em 1961 e publicado em 1974; Luanda, escrito em 1963 e publicado em 1964; Vidas Novas, escrito em 1962 e publicado em 1975; Velhas Estórias, publicado em 1974; No antigamente, na Vida, publicado em 1974; Nós, os do Mukulusu, publicado em 1975; Macandumba. publicado em 1978; João Vêncio: os Seus Amores, publicado em 1979.
} 
nascido em Vila Nova de Ourém, Portugal, em 04 de maio de 1935, o qual com menos de dois anos de idade, juntamente com seus pais mudou-se para Angola. Passara sua infância e sua juventude em Luanda. No início da guerra colonial, em 1961 contra o processo de colonização e engajando-se nas lutas pela libertação da Angola passou a fazer parte do Movimento Popular de Libertação da Angola (MPLA) tornando-se um participante na luta armada contra Portugal; porém, em 1959, estivera detido pela Polícia Internacional e de Defesa do Estado (PIDE), por ter se manifestado contra a ditadura. Fora nesse período que Luandino escreveu sua obra de contos Vidas Novas, o qual está incluso o conto O Fato completo de Lucas Matesso (LABAN, 1980).

Luandino Vieira: Sim, é correcto. Vidas Novas é um livro que planifiquei; foi escrito dia a dia. Uma história por dia, creio, mais ou menos. Mas muito antes de escrever estava tudo apontado: uma será sobre isso, outra sobre isto... discuti mesmo com Antônio Jacinto o plano antes de fazer, e depois fiz, escrevi e consegui fazer sair da cadeia esse manuscrito e...

Pergunta: Onde foi escrito?

Luandino Vieira: foi escrito na cadeia da PIDE, aqui em São Paulo, Luanda, para mandar um concurso da casa dos estudantes do Império. (LABAN, 1980, p. 34)

Desse ponto percebe-se a intensa ligação que há entre a ficção e a vida do autor, que expõe uma realidade sua em determinado momento de sua vida. Em 1959, Vieira volta a ser detido pela PIDE, sendo condenado a 14 anos de prisão no Campo de Concentração do Tarrafal, em Cabo Verde. Até 1964 passou por várias cadeias em Luanda. Em 1972 foi libertado e passou a viver em Lisboa até a Revolução dos Cravos; no entanto, em 1975, regressou a Angola, passando a assumir a função de diretor do departamento de orientação revolucionário 
do MPLA, coordenando o grupo até 1979. Passa a exercer também os mais diversos cargos, agindo ativamente em instituições ligadas à cultura, às artes e à educação, concomitante à atividade de escritor, contista e romancista.

Desiludido com o reinício da guerra civil em Angola, logo após as eleições de 1992, regressou para Portugal e por lá vive até os dias atuais na zona rural do Minho, próximo de Vila Nova de Cerveira. Laban (1980) expõe que Luandino, considerado cidadão angolano, frequentou e terminou o ensino secundário em Luanda, fora preso por suas atividades anticolonialista, cumpriu grande parte da sua pena no campo de concentração de Tarrafal. Após a independência de Angola, foi nomeado diretor do programa de televisão popular da Angola, além da direção do MPL, fora também secretário geral da União dos Escritores Angolanos.

Em 1964 sua obra Luanda ganhou o prêmio Mota Veiga (Prêmio D. Maria José Abrantes da Mota Veiga), o qual através de um júri formado por uma comissão, com a maioria dos votos, e mesmo estando preso, recebeu o prêmio, o qual fora representado pela sua esposa, Ermelinda Graça, pelas mãos do governador do distrito de Luanda, Joffre Pestanha, fato que fora noticiado pela imprensa angolana. Nesse mesmo ano, o jornalista português Roby Amorim, em seu trabalho na imprensa angolana, articulou uma palestra com o tema "Bases para uma literatura angolana”, evidenciando e consumando que, com essa obra, nascia a literatura angolana (LABAN 1980).

O sucesso dos escritos de Luandino é fruto dos muitos questionamentos que são colocados acerca do mundo angolano, a maior parte deles é resultado do seu período carcerário, na década de 1960. Sua marca está na diversidade do português trabalhado em suas obras, o qual convenciona a língua do colonizador em Angola. Um exemplo 
é a variação do léxico fato completo no conto analisado: ele preza por uma linguagem que abarque a diversidade portuguesa incluindo as falas dos nativos musseques da cidade de Luanda. Não é à toa que seus trabalhos têm gerado uma infinidade de análises comparativistas, como a que aqui, nesta pesquisa, é apresentada, em que se têm muitos estudos que o compara a Guimaraes Rosa. No entanto, aqui, busca-se fazer uma relação com os escritos de Haroldo Maranhão.

Luandino, em seus escritos, se apossa da língua do colonizador para, através do testemunho, expressar a sua realidade; sendo suas narrativas, como no conto analisado, uma descrição do que ocorria nos estabelecimentos prisionais, a essa manifestação do testemunho do colono Jean Paul Sartre, ao prefaciar o livro Os condenados da terra, evidencia que "Nossas vítimas nos conhecem por suas feridas e seus grilhões; é isto que torna seu testemunho irrefutável. Basta que nos mostrem o que fizemos delas para que conheçamos o que fizemos de nós”. (SARTRE apud FANON, 1968, p. 8). Assim, há uma reconstrução do que ocorria com os colonos nas cadeias angolanas, sendo elas testemunhadas, sentidas e conhecidas pelos leitores desse grande escritor, que mesmo nascido no país dos colonizadores, por amor a Luanda e a África, optou por se colocar como colonizado.

\section{O trauma a partir das torturas}

Experiências traumáticas, segundo Seligmann-Silva (2003), foram conceituadas por Sigmund Freud como aquelas situações de choque que não são assimiladas em sua totalidade quando ocorrem. Aqui, o testemunho entra como uma narração não completa desses fatos, sejam eles de batalhas ou acidentes. Trata-se, da: 
História de um choque violento, mas também de um desencontro com o real (em grego, vale lembrar, "trauma” significa ferida). A incapacidade de simbolizar o choque - $\mathrm{o}$ acaso que surge com a face da morte e do inimaginável — determina a repetição e a constante "posterioridade", ou seja, a volta après-coup da cena. (SELIGMANN-SILVA, 2003, p. 49).

Por essa lógica, trauma entra como um princípio formulador dentro desse novo campo literário, que é o da literatura de testemunho. Segundo Freud (1998), em sua obra Além do princípio do prazer,

o conceito de trauma implica necessariamente uma conexão desse tipo com uma ruptura numa barreira sob outros aspectos eficazes contra os estímulos. Um acontecimento como um trauma externo está destinado a provocar um distúrbio em grande escala no funcionamento da energia do organismo e a colocar em movimento todas as medidas defensivas possíveis. (FREUD, 1998, p. 19).

À vista disso, entende-se que o trauma, como meio de defenderse, pode causar um silenciamento ou necessidade de testemunho aos violentados. A esse respeito, Werner Bohleber (2007) elucida dois caminhos para o traumático: um, que o choque causado pelo trauma impede formulações acerca do trauma, devido encontrar-se em desamparo, sem relações afetivas e de comunicações internas; dois, que o choque traumático causa no indivíduo construções narrativas, no entanto, não se trata do evento traumático, mas possibilita que haja o testemunho. Portanto, esse processo de construção memorialista dos acontecimentos, bem como dos lugares nos contos, mostram um processo traumático que se evidencia a partir do testemunho. Justamente esse acontecimento traumático que colabora, em parte, para que haja o testemunho.

Partindo desse princípio, atuações mentais são produzidas por quem é traumatizado, em que ocorrem construções de testemunhos 
que garantem a literalização do trauma. Diante de cada caso traumático, possui uma manifestação especifica manifestada nas narrativas. Assim, narrar o trauma é impossível, o que se tem é uma narração constituída de testemunho (SELIGMANN-SILVA, 2003).

Novamente Seligmannn-Silva (2013), em uma entrevista para o programa de apoio a pesquisadores da Universidade Estadual de Campinas - UNICAMP, chamado Diálogo Sem Fronteira, elucida sobre essa nova concepção de trauma na literatura, com uma concepção moderna e contemporânea, usa das teorias de Freud para explanar esse novo conceito. Segundo ele, o trauma é um conceito surgido no século XX na psicanálise, mas que veio das teorias da medicina traumática, tratada como feridas psicológicas. Contudo, dentro da literatura de testemunho esse conceito psicanalítico se mantém, o qual se trata de uma ferida psicológica, mas de maneira mais aguçada, aqui passa a tratar-se de um ferimento que precisa de cuidados.

Nessa lógica, a narrativa de testemunho é uma abordagem da literatura de resistência, que abrange produções literárias de caráter memorialista, as quais são narradas por aqueles que se encontravam sob o domínio de regimes opressores. Seus relatos deslocam-se entre as lembranças e a incapacidade de esquecer-se dos fatos acontecido, utilizando-se das palavras e da escrita para narrar as experiências traumáticas que a memória se nega a esquecer.

O testemunho reside, assim, na rugosidade da distância insalvável entre a linguagem, o corpo e a experiência. Nele, repete-se infinitamente o silêncio que não se apreende como mutismo (ligado a uma negação ou a um excesso de palavras), mas como inscrição de uma força singular cuja sobrevivência se pressente no im-possível que o lança em devir. O testemunho é, nesse sentido, o movimento de atravessar o mundo com a matéria do silêncio que a memória desloca no corpo, fazendo emergir um texto impossível. O texto da vida. (VILELA, 2012, p. 177) 
Pouco já se comentou acerca das inúmeras catástrofes e violências que se sucederam a partir do século XX. Com um gigantesco número de pessoas torturadas e mortas, esse período traz à tona uma nova vertente de escritos literários, instaurando um novo modelo de escrita, não mais de caráter estilístico, mas sim, temático e conteudista, com uma linguagem que vem se ressignificar e descrever de maneira mais similar, justamente as frustrações desse momento histórico.

O termo Resistência e suas aproximações com os termos "cultura", "arte", "narrativa" foram pensados e formulados no período que ocorre, aproximadamente, entre 1930 e 1950, quando numerosos intelectuais se engajaram no combate ao fascismo, ao nazismo e as suas formas aparentadas, o franquismo e o salazarismo. O que os italianos chamavam de partigiani e os franceses logo traduziram como partisans significava participação, partido, luta de uma facção que se rebelou contra as milícias nazi-facistas que ameaçaram apossar-se da Europa no fim dos anos trinta e só foram derrotadas em 1945. Firmou-se ao longo desses anos sombrios uma frente de caráter libertador que, em luta de guerrilhas e emboscadas, o maquis (de macchia, no sentido corso de moita onde entocaiavam os resistentes), disputava palmo a palmo as áreas invadidas. (BOSI, 2002, p. 125)

Esse período é marcado por uma nova formulação no fazer artístico, cultural e narrativo, em que a resistência e sua carga significativa, e com um cunho libertador, trazem para os intelectuais desse período um meio de combater, através dos seus talentos, os variados grupos de opressão. Diante disso, surge uma variedade de textos que, a partir do seu estilo e das temáticas trabalhadas, elucidam a barbárie que foram os atos políticos que se instauraram no mundo a partir do século $\mathrm{XX}$, o qual:

Ao tomar contacto com essas obras, o leitor politizado do pós-guerra supôs que a natureza mesma do fenômeno literário houvesse mu- 
dado radicalmente e que, a partir da luta contra os regimes totalitários e belicistas, a escrita passara a ter a mesma substância cognitiva e ética da linguagem de comunicação, que é o nosso pão cotidiano quer na vida pública, quer na vida privada. A escrita ficcional teria passado a ser uma variante e, não raro, uma transcrição do discurso político ou da linguagem oral, de preferência popular. (BOSI, 2002, p. 126)

Nessa situação, tem-se uma descrição, mesmo que com uma linguagem oral e popular, da realidade vivida nesse período por pessoas que foram vítimas da crueldade totalitária. O que se tem nesse período é uma proposta neo-realista que significasse a libertação da escrita. "Novamente a resistência ético-política buscava traduzir-se em uma resistência no plano das opções narrativas e estilísticas.” (BOSI, 2002, p. 127).

Novamente Bosi (2002) elucida que a temática da resistência se torna universal dentro da cultura existencialista. Com uma dimensão ética e uma atitude que transcende aos que são considerados de direita e contra o nazifascismo. Para Sartre e Camus, trata-se fundar palavras radicais antiburguesia, que, não conformada, busca revolucionar construindo, assim, um novo homem. Diante disso, "Em termos de criação narrativa, o importante é ressaltar a coexistência de absurdo e construção de sentido, de desespero individual e esperança coletiva; em suma, de escolha social arrancada do mais fundo sentimento da impotência individual.” (BOSI, 2002, p. 128).

Seligmann-Silva (2008) elucida sobre a cena da literatura de teor testemunhal, e a sua noção "literatura de testemunho”, é mais utilizada no âmbito anglo-saxão. Nesse ponto são pensados os tribunais do pósguerra, dado a origem do testemunho, bem como os diálogos com os estudos literários latino-americanos, onde esse termo testimonio exerceu um papel de grande importância a partir dos anos de 1970. 
Não procura-se normalmente nessa bibliografia definir de modo estrito qual seria a literatura de testemunho: de um modo geral, tratase do conceito de testemunho e da forte presença desse elemento nas obras de sobreviventes ou de autores que enfocam as catástrofes (guerras, campos de concentração etc., predominantemente do século XX). [...] . Com os estudos que realizam paralelos entre o testemunho da Shoah e o do Gulag, bem como com obras de (ou sobre) sobreviventes de outros genocídios e catástrofes estabeleceuse uma nova área dedicada ao estudo comparado dos genocídios. (SELIGMANN-SILVA, 2008, p. 20).

Sendo assim, esse tipo de testemunho utiliza-se da literatura e da ficção para através dela testemunhar, de maneira realista, as atrocidades, os genocídios, a situação traumática e corporal dos que vivenciaram ou não o período do pós-guerra.

Nos estudos de testemunho deve-se buscar caracterizar o "teor testemunhal" que marca toda obra literária, mas que aprendemos a detectar a partir da concentração desse teor na literatura e escritura do século XX. Esse teor indica diversas modalidades de relação metonímica entre o "real” e a escritura. (SELIGMANN-SILVA, 2005, p. 85).

Diante disso, são criados variados meios testemunhais que elucidam esse processo de escrita e expressam a situação do sobrevivente, além dos supracitados, há também, segundo Seligmann-Silva (2008) outro parentesco semântico dessa noção, são elas: superstes e testis.

Verificamos a diferença entre superstes e testis. Etimologicamente, testis é aquele que assiste como um «terceiro» (terstis) a um caso em que dois personagens estão envolvidos; e essa concepção remonta ao período indo-europeu comum. Um texto sânscrito enuncia: «todas as vezes em que duas pessoas estão presentes, Mitra está lá como terceira pessoa»; assim o deus Mitra é, por natureza, a «testemunha». Mas superstes descreve a «testemunha» seja como aquele «que subsiste além de», testemunha ao mesmo tempo sobrevivente, 
seja como «aquele que se mantém no fato», que está aí presente. (BEVENISTE apud SELIGMANN-SILVA, 2008, p. 178).

Ainda Seligmann-Silva (2008) evidencia que Benveniste, a partir dessa citação, apresenta a proximidade e contaminação semântica entre esses dois sentidos, em que o martir moderno aproxima-se do testemunho como testis, agora o superstes foca-se na audição, enquanto testis foca-se na visão já que possui uma concepção instrumental da língua, crendo na possibilidade de circular entre o tempo da cena histórica e o tempo em que ela se escreve.

Nessa acepção, as narrativas de teor testemunhal são literaturas de testemunho que através da ficção reconstitui e descreve acontecimentos com base em experiências reais de um alguém que testemunhou um fato memorialista. Diante disso, tem-se em parte, um processo de "reconstrução" que a partir de relatos traumáticos da voz aos sobreviventes e as minorias. Por esse viés,

Não podemos pensar em literatura de testemunho sem ter em mente essa concepção anti-essencialista do texto. Nesse gênero, a obra é vista tradicionalmente como a representação de uma "cena”. Mas qual é a modalidade dessa representação? Certamente não podemos mais aceitar o seu modelo positivista. O testemunho escrito ou falado, sobretudo quando se trata do testemunho de uma cena violenta, de um acidente ou de uma guerra, nunca deve ser compreendido como uma descrição "realista” do ocorrido (SELIGMANN-SILVA, 2008, p. 10).

Como toda catástrofe é carregada de traumas, é importante esclarecer que o testemunho não é uma descrição total do ocorrido. O que se tenta expressar com isso, que, é, impossível descrever em sua totalidade o trauma, sempre haverá algo que ficou e não pode ser dito, por isso usa-se o termo recriar para assim tentar ao máximo narrar esse trauma da maneira mais verossímil possível. Desse modo, 
[..] há, em suma, inúmeras modalidades de testemunho, seja em relação a situações, eventos, períodos (Shoah, Gulag, genocídios, guerras, ditaduras, tortura, miséria, opressão etc.), seja em relação a formas de expressão do testemunho (memória, romance, filme, depoimento, poema, quadrinhos, canções, etc.). (SALGUEIRO, 2012, p. 286).

Portanto, nesse contexto de análise literária e histórica que este conto pode ser analisado, sendo ele parte desse acervo que se encontra inserido nos escritos de teor testemunhal, apresentando situações traumáticas a partir da tortura representada pelos atos acometidos a Lucas Matesso.

\section{O Conto O fato completo de Lucas Matesso}

O conto de Luandino Vieira fora publicado diretamente na coletânea Vidas Novas, primeiramente em Paris, sem data e revisão do autor, o qual só em 1975 os publicou em território africano pela União dos Escritores de Angola (UEA). Com uma escrita não linear, apresentando um narrador onisciente, o conto narra a tortura passada em cárcere por Lucas Matesso, ou preso 16, que ocorriam no governo salazarista em Luanda, na Angola. Representa, além disso, de maneira metafórica, a ignorância dos torturadores em compreender a variação lexical diante do termo fato completo.* Dessa forma, a obra* apresenta a vida carcerária dos presos políticos que combatiam ou eram suspeitos de envolvimento com grupos de combate ao colonialismo.

O conto do angolano busca, por meio de um estilo de escrita muito pessoal, registrar as relações, ora de acordo, ora confusas, entre a linguagem do dominador e as mais diversas conotações semânticas, que os dominados, os subjugados das antigas colônias portuguesas em África, mais especificamente na Angola, dão às palavras e expressões 
da língua portuguesa naquele país.

Associando este fato a um contexto de ditadura e, portanto, de crise política, cultural e perseguição a tudo aquilo que divergia da ideologia da elite dominante, Luandino Vieira constrói literariamente um drama comum durante aquele período de obscurantismo salazarista, onde o ditador expande o braço repressor de seu governo antidemocrático, autoritário e violento aos territórios subjugados por Portugal.

A máquina ditatorial de Salazar cria um ambiente repressivo em que a vítima Lucas Matesso, um preso político, acusado de subversão, é encarcerado e aviltado por um interrogatório inócuo em que a tortura física é instrumento essencial de coleta de informações, de delações, mas mais do que isso: de demonstração de obediência à autoridade central da ditadura, de forma a exibir serviço perante os agentes superiores do governo de Oliveira Salazar.

Adentrando o personagem Lucas Matesso, ou preso 16, que faz referência ao número da sua cela, é um prisioneiro político de Luanda por suspeita de ligação com o Kongo, ${ }^{6}$ o qual é torturado durante três meses em busca do chefe do seu bando, no caso Domingos André.

O bufo que tinha-lhe queixado jurava que o rapaz tinha ligação com o Kongo, mas em três meses de interrogatórios, porrada todas as vezes, dias sem comer e sem tratamento.

[...] Esse sacana do Lucas João Matesso, da cela 16.

[...] - Artur traga-me o 16!

[...] Domingos não lhe apanhavam, já tinha ido mesmo no Kongo. (VIEIRA, 1997, p. 74, 76, 78).

\footnotetext{
${ }^{6}$ Trata-se de participantes da União das Populações Angolanas (UPA) antiga União das Populações do Norte de Angola (UPNA), dentre eles exilados bakongo no congo da Belga, que entre suas muitas lutas, buscavam pela restauração do antigo reino do Kongo, com a mítica capital, S. Salvador do Congo, em território angolano.
} 
O caso de Lucas Matesso é curioso, já que após três meses de prisão ele nada confessara de relevante para os agentes repressores. Nesse diálogo com o personagem, Brait (1985) esclarece sobre a função discursiva perante a narrativa, em que sua importância e seu sucesso estão estritamente ligados ao fazer artístico do autor, sendo esta outra questão que também é importante considerar nos textos. Portanto,

Tanto o conceito de personagem quanto a sua função no discurso estão diretamente vinculados não apenas à mobilidade criativa do fazer artístico, mas especialmente à reflexão a respeito dos modos de existência e do destino desse fazer. Pensar a questão da personagem significa, necessariamente, percorrer alguns caminhos trilhados pela crítica no sentido de definir seu objeto e buscar o instrumental adequado à análise e à fundamentação dos juízos acerca desse objeto. (BRAIT, 1985, p. 27).

Dado isso, infere-se acerca do momento histórico em que vivia o autor, o qual alude mesmo que em parte a sua trajetória, desacordos e violências sofridas a partir dos padrões sociais em período de censura e opressão. Os acontecimentos dados aos personagens estão direcionados a um ato reflexivo exposto pelo autor. Esse processo se dá por meio de seu objeto (personagem) que critica, define e se fundamenta apoiado em seu juízo de valor. Contudo, é necessário entender que não se deve associar as personagens com os reais indivíduos em sua totalidade, mas sim, associar suas características e seus comportamentos narrativos ao que verdadeiramente é real.

As pessoas reais, assim como todos os objetos reais, são totalmente determinados apresentando-se como unidades concretas, integradas de uma infinidade de predicados, dos quais somente alguns podem ser "colhidos" e "retirados” por meio de operações cognoscitivas especiais. Tais operações são sempre finitas, não podendo por isso nunca esgotar a multiplicidade infinita das determinações do ser real, 
individual, que é “inefável”. (CANDIDO, 1972, p. 33).

Os personagens são partes de uma história narrada que está ligada à realidade. O que acontece nesse caso, são personagens verossímeis ao real, que, com concepções próprias, baseiam-se em uma pessoa não fictícia, mas nunca na sua totalidade. Além disso, é necessário entender que "é, porém, a personagem que com mais nitidez torna patente a ficção, e através dela a camada imaginária se adensa e se cristaliza” (CANDIDO, 1972, p. 13-14). É a partir delas que as narrativas se tornam claras, pois é nelas que o fictício se completa e se fixa, onde se aprende que o núcleo principal da narrativa gira em seu torno.

Por esse viés, segundo Sarmento-Pantoja (2014), o narrador entra como ponto chave, ele é o responsável pelo ethos, ou seja, o caráter moral que evidencia os acontecimentos de caráter social de determinado período catastrófico. Essa situação se concretiza na medida em que se criam os personagens, moldando-se no decorrer das narrativas suas personalidades, sendo elas "boas” e "más”, que a partir de um campo ético constituem posições de caráter valorativo indispensáveis à sociedade. Assim, os processos de resistência aparecem por rumos que por hora se opõem, já que apresentam posições com “mão de duas vias".

Ao que está supracitado, percebe-se a importância do personagem para relatar as torturas causadas nesse período de violência, sendo ele um ponto chave utilizado pelo autor. Dessa maneira, adentra-se a tortura, temática usada pelos autores para evidenciar esses atos atrozes acometidos aos presos políticos em período de opressão na Angola. Diante disso, na $3^{\mathrm{a}}$ pessoa, Luandino Vieira expressa as experiências e violências vividas em período ditatorial.

Nesse contexto, a temática da tortura, torna mais evidente as re- 
flexões políticas, sociais e culturais causadas pelo uso de atrocidades na obra, que em Luandino Vieira esse processo de opressão se destaca através das violências cometidas contra Lucas Matesso, que é surrado inúmeras vezes como meio de delatar Domingos, chefe de um dos grupos contrários aos ideais salazaristas.

Uma coisa por ali e por acolá, conversas sem importância, mas nem um nome. Chamava-lhe para interrogatório pela noite dentro, mandava-lhe molhar o corpo antes de o ajudante lhe arrear uma surra de cavalo-marinho, o homem torcia, gemia, borrava às vezes, pedia perdão, mas, bem espremido como ele sabia fazer, não deitava nada. (VIEIRA, 1997, p. 74).

A máquina ditatorial de Salazar cria um ambiente repressivo em que a vítima Lucas Matesso, um preso político, acusado de subversão, é encarcerado e aviltado por um interrogatório inócuo em que a tortura física é instrumento essencial de coleta de informações, de delações, mas mais do que isso: de demonstração de obediência à autoridade central da ditadura.

Os torturadores o mantêm preso por puro sadismo, como se pode ver descrito no início do conto, mas também, usando-o como oportunidade de ascensão de carreira dentro da corporação ditatorial.

Mas o inspetor não quisera mais ouvir-lhe as desculpas que estava arranjar, a cabeça cheia desse exame que chegava e uma raiva a encher-lhe o peito curto, uma vontade de rebentar de porrada esse cão do Lucas Matesso, fazer-lhe confessar qualquer coisa, nem que fossem mentiras não fazia mal. Era preciso apresentar o processo ao inspetor, era a sua fama, a sua carreira que estava ainda em perigo. (VIEIRA, 1997, p. 75).

Há, portanto, motivos que vão além da pura acusação de subversão; os agentes da repressão também refletem, em suas ações, os seus interesses pessoais que, dentro da variedade de funções da estrutura 
estatal de coerção, ambicionam os cargos de melhor remuneração e melhor posição social. Essa mixórdia de intensões apenas agravava sobremaneira a situação de sua vítima, agora mais do que nunca à mercê das mais sádicas arbitrariedades.

Por isso ria agora baixinho, satisfeito, esfregando as mãos contentes, engelhando a cara para esconder os olhinhos maus, pensando que sim, era agora que lhe caçava, esse tipo tinha esperado três meses e agora ia talvez receber algum recado. Já sentia o chicote a berrar em cima da pele do homem, os gritos, as desculpas que ele punha sempre, aquele prazer que lhe entrava no corpo quando acendia o cigarro e se encostava na cadeira para começar ditar no ajudante:

—... declarou que .... (VIEIRA, 1997, p. 75).

Outro ponto que também evidencia a tortura nessa obra é com relação a variação lexical dada ao fato completo, que em Portugal faz referência a roupas, e na Angola, é um prato típico da região. Essas questões levaram o personagem a sofrer ainda mais com a violência militante, que sem um entendimento e conhecimento diante da versatilidade desse vocábulo continuará a flagelar sem piedade Lucas Matesso.

[...] A mulher do Gajo falou-lhe baixinho em mandar o fato completo!

— O fato completo?...

— Sim, chefe! Foi isso que a tipa disse!

[...] No chão de cimento o homem tinha espalhado todas as roupas limpas Lucas Matesso ia receber nessa manhã.

— Mas não veio o fato?

— Não, chefe! Veio comida, dessa comida que esses gajos comem, com aquela porcaria do azeite amarelo, e esta roupa.

[..] Essa comida de feijão de azeite-palma com peixe de azeitepalma, a banana e tudo, que toda a gente nos musseques tem só 
a mania de chamar de "fato completo". (VIEIRA, 1997, p. 73, 79, 86)

Lucas Matesso havia recebido por cinco minutos a visitar de sua mulher, descrita pelo guarda prisional como "apesar de preta, é muito boa...” (VIEIRA, 1997, p. 73), em que depreende-se a ideia de ela ser nativa, angolana, e a partir dessa visita, Luandino constrói a trama que culminará no clímax do conto, ironizando a capacidade intelectual dos agentes da ditadura, bem como explicitar a dimensão da diversidade linguística do mesmo idioma como fator de confusão a toda tentativa de interpenetração de culturas por meio da força.

— Tudo ocorreu às mil maravilhas. Cinco minutos pró gajo ver a mulher. Apesar de preta, é muito boa...

— Diga lá a novidade, carago! Está-me a fazer água na boca!

O velho guarda prisional riu com a confiança desse chefe que podia mesmo ser ainda filho dele:

— Ora, quer saber?! No fim da visita os sacanas abraçaram-se para se despedirem e julgaram que eu não estava a ouvir. Ah, ah, ah! A mulher do gajo falou-lhe baixinho em mandar o fato completo!

- O fato completo?...

— Sim, chefe! Foi isso que a tipa disse!

- $\mathrm{P}^{\prime}$ ra que raio quer esse gajo o fato completo com este calor? $\mathrm{Ou}$ o sacana pensa que o processo dele vai para tribunal?! (VIEIRA, 1997, p. 73-74)

Ironicamente, Luandino satiriza a ignorância linguística dos agentes da tortura, mas também registra o fenômeno da variação linguística naquele país lusófono. A questão dramática desse fator cultural implica num ato que vai além das discussões entre linguistas, ela é causadora de violência direta contra os inimigos da elite dominante, que por meio dos mecanismos repressivos que ela dispõe, submetem 
suas vítimas a situações de extremo sofrimento, como é o caso de Lucas Matesso.

Sem horário ou data marcada, Lucas Matesso sofria inúmeras torturas durante o período em cárcere, em momentos de interrogatório, sem uma comunicação com seus torturadores agonizará em dor e angustia durante três meses. Assim, o narrador descreve como ocorriam as violências ditatoriais que envolve o momento histórico da ditadura na Angola.

Ainda nem tinha dado um passo no gabinete, estava a olhar o chefe a sorrir bondoso, quando o chicote lhe apanhou num rio de fogo do pescoço até nos rins, colocando a camisa velha na pele. Lucas Matesso, apanhando assim à toa, gritou, cobrindo a cara com as mãos, já sabia o ajudante do chefe ia lhe bater mesmo na cabeça como era mania dele. O riso de mabeco do homem misturou-se nesse fogo de jindungo na pele e, na cara dele, o chefe, estava-lhe já a berrar:

— Tudo! Tudo! Quero tudo! Hoje não é como as outras vezes!

E o chicote atirava-se para lhe apanhar nas costas, na frente, torcendo-lhe o corpo que ele queria ainda fazer direito, quieto, e abrindo a boca que ele queria mesmo fechada, calada, sem uma palavra de perdão para esses homens, três meses ali e sempre com a pancada no corpo, na cabeça, parecia a vida deles não sabia mais nada, só bater, só arrear. $\mathrm{O}$ ajudante ria e levantava o braço gordo bem alto para deixar cair com força o grosso chicote que punha um barulho diferente nessa manhã bonita. Chamados pelos gritos do preso, os cães correram e adiantaram ladrar-lhe, trazendo mais confusão nos pés que arrastavam no cimento, no barulho da cadeira a cair com Lucas Matesso batendo com a cabeça no chão, o chicote sempre a arrear-lhe, e então, quando ia mesmo falar, perdão, para ver ainda se o chefe parava, a voz rouca e má entrou-lhe nas orelhas:

— Pronto! Ó Adão! Um balde de água!

A água estava fria, era boa assim encima o fogo a doer nas costas, a queimar, e um princípio de calma invadiu-lhe para lhe lembrar essa hora agora era perigosa, tinha de aguentar bem...

— Levanta-te! Quem é gajo? Anda, fala depressa! 
— Não conheço, nosso chefe! Já falei não conheço...

— Schcht! Cala-te! Quem é o gajo da fábrica, depressa!

O ajudante chegou-se, mansinho, mabeco de olhos a luzir com aquela carne assim de borla, balançando e fazendo gemer o chicote. (VIEIRA, 1997, p. 81-82).

É nesse contexto narrativo que o conto enfatiza momentos de tortura que se repetem constantemente: "O chefe agarrou no balde da água e despejou outra vez na cabeça ensanguentada, no corpo rasgado de Lucas Matesso.” (VIEIRA, 1997, p. 84). Todas essas violações ao corpo testemunham uma contínua realidade sangrenta, em que a África se viu inserida até as décadas finais de sua colonização.

Nesse cenário narrativo que interliga ficção e realidade, evidenciase os escritos de Seligmann-Silva (2010), segundo ele:

O testemunho tanto artístico/literário como o jurídico pode servir para se fazer um novo espaço político para além dos traumas que serviram tanto para esfacelar a sociedade como para construir novos laços políticos. Esta passagem pelo testemunho é, portanto, fundamental tanto para indivíduos que vivenciaram experiências-limite, como para sociedades pós-ditadura. (SELIGMANN-SILVA, 2010, p. 12).

Por esse viés, abre-se espaço para supor a partir da vida de Luandino Vieira e sua narrativa, que trata-se de uma escrita de teor testemunhal, que se concretiza no seu fazer literário, dando espaço para expor um novo lado político, nesse caso os das minorias que se uniam em grupos para lutar contra os regimes de opressão. Assim, seus textos podem ser considerados como escritos da literatura de resistência.

Portanto, é nesse contexto de violência assinalado que se discute a temática da tortura. Alfredo Bosi escreve no seu livro Literatura e Resistência que “a resistência se dá como tema” (BOSI, 2000, p. 120), considerando o significado da palavra resistir, compreende-se que o 
autor atribui essa definição justamente ao sentindo de se manter firme, de não ceder ao choque causado pelo outro, assim, o tema nos textos de resistência traz vida, estimulo para se ir contra o choque, ele traz a liberdade necessária para se expor uma realidade silenciada que de maneira gradativa se expõe traves do símbolo. Através do tema,

A situação do romancista é outra. Ele dispõe de um espaço amplo de liberdade inventiva. A escrita trabalha não só com a memória das coisas realmente acontecidas, mas com todo o reino do possível e do imaginável. O narrador cria, segundo o seu desejo, representações do bem, representações do mal ou representações ambivalentes. Graças à exploração das técnicas do foco narrativo, o romancista poderá levar ao primeiro plano do texto ficcional toda uma fenomenologia de resistência do eu aos valores e antivalores do seu meio. (BOSI, 2000, p. 121).

Sarmento-Pantoja (2014) em seus estudos acerca desse período de catástrofes e testemunhos também discute a resistência elucidada nos textos segundo o uso de temas e, para ela, quando a resistência passa a se expressar através de temas, cabe ao narrador manipular os fatos expostos, o qual usa da historiografia para desenvolver sua narrativa. Assim, o uso da temática nesses textos justifica-se a partir de um acontecimento histórico, situado no tempo e no espaço. A resistência, nesse sentindo, encontra-se situada a partir da sua ligação e manifestação de um estado de exceção, o qual vem sempre ferir os valores fundamentais da humanidade.

Desse modo, Sarmento-Pantoja (2014) evidencia justamente o que ocorre nos contos de Luandino Viera, em que a partir do tempo do salazarismo, em espaços diferenciados, Angola, com o uso da temática da tortura, desenvolvem em suas narrativas situações e acontecimentos históricos que discutem a resistência manifestada pela escrita de teor testemunhal, trazendo valores e oportunidades aos que até en- 
tão eram oprimidos, reconhecendo os seus direitos de expressar seus ideais.

Segundo Pilar Calveiro (2006), a tortura é uma experiência muito mais comum do que queremos aceitar. É mais fácil falar delas em suas expressões passadas do que as torturas que se manifestam no tempo presente. No entanto é mais pertinente que se faça o contrário e, assim, se perceba a sua atuação em modalidades atuantes que se necessita determinar. Em síntese, o principal objetivo da tortura está na busca por informações.

Pode-se conhecer variados meios de tortura e seus sentidos, as formas que ela assume dependem em cada momento, são funcionais ao poder especifico que as aplica. Essas formas atuais de tortura permitem dá pistas que compreendem as transformações do poder político, ainda que seja de uma maneira muito preliminar. A sua primeira função está na intenção de iniciar no prisioneiro uma ilegalidade estatal, marcando sobre o seu corpo as novas regras, impondo limites e respeito ao mundo e sobre o direito de protegê-lo. A sua segunda função está ligada à intenção de obter informações úteis que o preso sequestrado pode ter. Este foi o objetivo que a tortura atuou de maneira mais eficiente. Outro ponto de atuação da tortura é quanto a sua atuação como uma mensagem de aviso a todos, já que, através das vítimas, cria efeitos sobre a sociedade (CALVEIRO, 2006).

Portanto, diante das discussões apresentadas percebe-se que a representação da tortura nos contos torna conhecido vários meios de violência que eram utilizadas nos cárceres durante a ditadura militar. Todos esses pontos observados a partir do tema trabalhado e da sua realidade histórica, social e geográfica evidencia esses meios diferentemente. 


\section{Conclusão}

Finalizando essa proposta de reflexão teórica, ao analisar o conto O fato completo de Lucas Matesso de Luandino Vieira e considerando as teorias apresentadas, enfatiza-se que mesmo tratando-se de narrativa de teor testemunhal, os fatos aqui narrados não conseguem descrever em sua totalidade a realidade passada por presos políticos, já que há uma incapacidade memorialista por parte do torturado de simbolizar o choque, ou seja de narrar com total eficácia a história do trauma, o qual desloca-se entre o esquecimento, a alucinação e a incapacidade de esquecer fatos acometidos.

A literatura comparada fora um método de extrema importância para que se pudesse desenvolver este trabalho, já que a partir do seu caráter interdisciplinar, possibilitou que se adentrasse a outras áreas do conhecimento para compreender como as experiencias traumáticas estavam inseridas nas obras a partir da temática da tortura.

Desse modo, a obra angolana por meio do léxico em O Fato Completo exemplifica, literariamente, relações e conflitos entre a linguagem do dominador e sua diversidade semântica e a linguagem do dominado, mais especificamente nas colônias portuguesas em Angola, no qual os nativos dão significado próprio a alguns verbetes e expressões da língua portuguesa naquele país.

Assim, é dentro desse contexto ditatorial que Luandino cria uma obra literária enfatizando um drama de crise política e cultural, no qual o perseguido é considerado um divergente da ideologia dominante, a opressão salazarista, em que o ditador é personificação do braço repressor de seu próprio governo antidemocrático, autoritário e violento nos territórios subjugados pela central do regime: Portugal. Então, a máquina ditatorial do próprio ditador cria um meio repressivo em que 
a vítima, Lucas Matesso, é encarcerada. Nesse ponto, a tortura do corpo é um instrumento substancial para se conseguir informações, e mais do que isso: é uma estratégia de dominação e amostra pública de obediência irrestrita à autoridade central da ditadura, além de ser, por parte dos membros da forca repressiva de apresentar serviço perante os agentes superiores do governo de Oliveira Salazar.

Diante disso, tem-se nos contos o testemunho marcado pela violação do copo e da alma, nascendo, dessa forma, a experiência traumática e concomitante a isso, gerando também, a descrição da dor, das vivências impressas ao corpo. Assim, a literatura de testemunho entra como um meio de fazer justiça aos traumatizados, o qual os dá a possibilidade de narrar o que vivenciou, dando voz aos marginalizados e oprimidos.

Por esse viés, compreende-se que o corpo torturado a partir da literatura de testemunho passa ater um enfoque diferenciado, o qual considerando a teoria literária de que trauma passa a ser sinalizado como ferida psíquica a ser cuidada, o corpo passa a ser usado com uma característica de movimento entre o silencio e a voz, em que suas marcas fazem surgir o texto da vida.

Sendo assim, ao que está supracitado percebe-se a genialidade de Luandino Vieira. A partir dos seus escritos continua a cativar leitores e pesquisadores através do tempo e do espaço, o qual propicia elucidações críticas necessárias e significativas no meio acadêmico, em que marca positivamente o mundo literário contemporâneo.

\section{Referências}

BOHLEBER, Werner. Recordação, trauma e memória coletiva: a luta pela recordação em psicanálise. Revista brasileira de psicanálise, vol. 41, n. 1, p. 154-175, mar. 2007. 
BOSI, Alfredo. Literatura e Resistência. São Paulo: Companhia de Letras, 2002.

BRAIT, Beth. A personagem. 3. ed. São Paulo: Ática, 1985.

CALVEIRO, Pilar. La decisión política de torturar. In: SUBIRATS, Eduardo. Contra la tortura. México: Fineo, 2006.

CANDIDO, Antônio. A Personagem de Fiç̧ão. São Paulo: editora Perspectiva, 1972.

CARVALHAL, Tânia Franco. Literatura Comparada. 4. ed. São Paulo: Editora Ática, 2006.

CASCUDO, Fernando Luiz da Câmara. Angola: A guerra dos traídos*. Rio de Janeiro, Bloch Editores S A, 1979.

CLAUDON, Francis; HADDAD-WOTLIG, Karen. Elementos de Literatura Comparada: Teorias e métodos da Abordagem Comparatista. Tradução de Luís Serrão. Portugal: Inquérito, 1992.

FANON, Frantz. Os condenados da terra. Tradução de Laurênio de Melo. Rio de Janeiro: Civilização Brasileira, 1968.

FREUD, Sigmund. Além do princípio do prazer, psicologia de grupo e outros trabalhos. Edição Standard Brasileira das Obras Completas de Sigmund Freud, vol. XVIII. Rio de Janeiro: Imago, 1998.

HISTÓRIA Geral de Angola. Argélia: Edições Afrontamento, 1965.

HOBSBAWM. Eric J. A era dos extremos. O breve século XX (1914-1991). São Paulo: Companhia das Letras, 1995. Instituto Paulo Freire, 2004. Disponível: www.paulofreire.org. Acesso em 23/10/2020.

LABAN, Michel (et al). Luandino: José Luandino Vieira e sua obra. Lisboa: Edições 70, 1980.

MACHADO, Álvaro Manuel; PAGEAUX, Daniel-Henri. Da literatura comparada à teoria da literatura. 2 ed. Lisboa: Presença, 2001.

MARTINS, J. P de Oliveira. O Brasil e as colônias portuguesas. 5 ed. Lisboa: Livraria Editora Zamparoni, 1920.

MAZULA, Brazão. Moçambique: Eleições, Democracia e Desenvolvimento. Maputo: Inter-África Group, 1995.

MENESES, Filipe Ribeiro. Salazar: biografia definitiva. São Paulo: Leya, 
2011.

NESTROVSKI, Arthur; SELIGMANN-SILVA, Márcio. (orgs.) Catástrofe e representação. São Paulo: Escuta, 2000.

PINTO, António Costa. O salazarismo e o fascismo europeu. In: ROSAS, Fernando: BRITO, J. M. Brandão de. Salazar e o salazarismo. Lisboa: Publicações Dom Quixote, 1989.

ROSAS, Fernando: BRITO, J. M. Brandão de. Salazar e o salazarismo. Lisboa: Publicações Dom Quixote, 1989.

SALGUEIRO, Wilberth. O que é literatura de testemunho: considerações em torno de Graciliano Ramos, Alex Polari e André DuRap. Matraga, Revista do Programa de Pós-Graduação em Letras da UERJ. Rio de Janeiro, UERJ, v. 19, n. 31, jul./dez. 2012, p. 284-303.

SARMENTO-PANTOJA, Tânia. (org.). Arte como provocação à memória. Curitiba: CRV, 2014.

SELIGMANN-SILVA, Márcio. “Zeugnis” e “Testimonio”: um caso de intraduzibilidade entre conceitos. Pandaemonium germanicium, 06/2002. p. 6783.

(org.). História, memória, literatura: o Testemunho na Era das Catástrofes. Campinas: Editora da UNICAMP, 2003.

. Testemunho e a política da memória :o tempo depois das catástrofes. Revista Projeto. História. Volume 30, jun 2005. p. 71-98. Disponível em: www.pucsp.br Acesso em: 20/10/2020.

. Testemunho da Shoah e literatura. Revista Eletrônica Rumo à tolerância. FFLCH-IEL-UNICAMP, 2008, p. 16. Disponível em: www.rumoatolerancia.fflch.usp.br. Acesso em: 10/10/2020.

- O Local do Testemunho. Revista do Programa de Pós-Graduação em História. Florianópolis, v. 2, n. 1, p. 3-20, jan. / jun. 2010.

História, Memória e Trauma. Programa Diálogo sem Fronteira. CEAv Unicamp. programa de apoio a pesquisadores da Universidade Estadual de Campinas - UNICAMP. 2013. Disponível em: www.youtube.com. Acessado em: 10/10/2020.

VIEIRA, José Luandino. Vidas Novas. 3. ed. Lisboa: edições 70, 1997.

VILELA, Eugénia. Do testemunho. Revista de Filosofia Princípios. Natal 
(RN), v. 19, n. 31 janeiro/junho de 2012, p. 141-179.

VISENTINI, Paulo G. Fagundes. As revoluções africanas: Angola, Moçambique e Etiópia. São Paulo: Editora UNESP, 2012.

WHEELER, Douglas; PÉLISSIER, René. História de Angola. Lisboa: Tinta-dachina, 2009. 


\title{
Resumo:
}

A partir do método da literatura comparada este artigo analisa o O fato completo de Lucas Matesso (1997) de Luandino Vieira e as torturas que nele estão descritas. Nesse viés, o objetivo do trabalho está em refletir as experiências de traumas depositadas ao corpo após o processo de tortura, concomitante a isso refletir as violências acometidas contra o personagem Lucas Matesso diante dessa obra de teor testemunhal. Portanto, a manifestação literária representada pelos contos, no contexto contemporâneo da literatura brasileira e angolana, permite perceber a violência ditatorial e a resistência por parte dos encarcerados, na qual mostra a atrocidade e a brutalidade sofrida por eles, apresentando um cenário real vivenciado por países que até os dias atuais resistem as repressões ditatoriais.

Palavras-chave: Tortura; teor testimonial; Lucas Matesso; Luandino Vieira; Salazarismo.

\begin{abstract}
:
Using the method of comparative literature, this article analyzes the complete fact of Lucas Matesso (1997) by Luandino Vieira and the tortures described in it. In this bias, the objective of the work is to reflect the experiences of traumas deposited on the body after the torture process, concomitant to this to reflect the violence suffered against the character Lucas Matesso in the face of this work of testimonial content. Therefore, the literary manifestation represented by the tales, in the contemporary context of Brazilian and Angolan literature, allows to perceive the dictatorial violence and the resistance on the part of the prisoners, in which it shows the atrocity and brutality suffered by them, presenting a real scenario experienced by countries that until today resist dictatorial repressions.
\end{abstract}

Keywords: Torture; testimonial content; Lucas Matesso; Luandino Vieira; Salazarism. 
Recebido para publicação em 30/10/2020.

Aceito em 08/01/2021. 